\title{
Maisonneuve fracture: a type of ankle fracture
}

\author{
Ryota Inokuchi, ${ }^{1}$ Yasuyuki Jujo, ${ }^{2}$ Kosui Iwashita, ${ }^{2}$ Masato Takao ${ }^{2}$
}

${ }^{1}$ General and Emergency Medicine, Jujo Hospital, Kisarazu, Chiba, Japan ${ }^{2}$ Clinical and Research Institute for Foot and Ankle Surgery, Jujo Hospital, Kisarazu, Chiba, Japan

\section{Correspondence to} Dr Ryota Inokuchi; intensivecareunits@gmail.com

Accepted 28 September 2019

\section{DESCRIPTION}

A healthy, 41-year-old man sustained a left ankle injury, resulting in persistent pain that was initially diagnosed as an ankle sprain without radiographic abnormalities. Further examination at our hospital showed medial malleolus and left proximal fibula tenderness; pain on manual compression of the proximal tibia and fibula suggested tibiofibular syndesmosis injuries. Plain, full-length tibial and fibular radiography revealed an oblique fracture through the proximal diaphysis of the left fibula (figure 1). Maisonneuve fracture typically involves deltoid ligament rupture, tibiofibular ligament disruption and a spiral fracture of the proximal fibula. ${ }^{1}$ Syndesmosis injuries involve multiple ligaments between the distal tibia and fibula; restoring their association is key to effective treatment. ${ }^{2}$ Because delayed surgical intervention prolongs ankle pain, open reduction and internal fixation are generally performed. ${ }^{3}$ This patient underwent suture

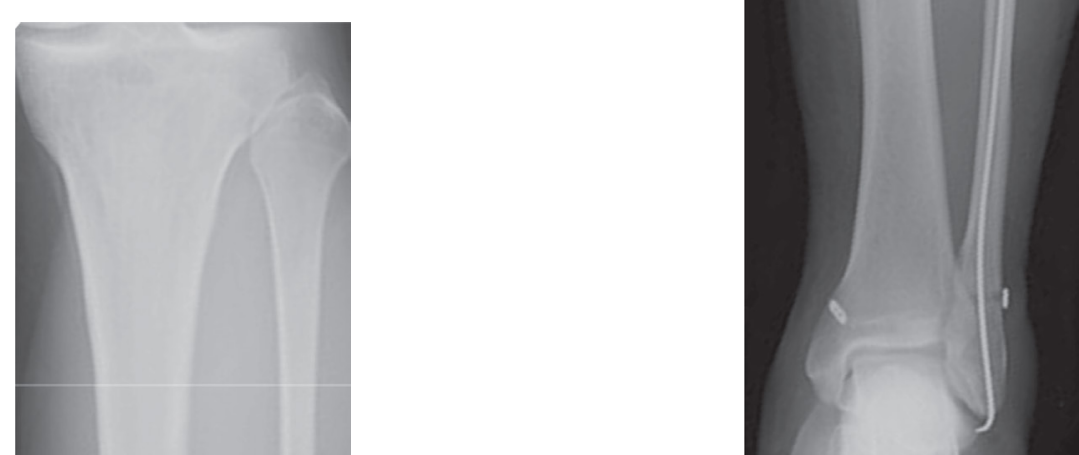

Figure 2 X-ray showed suture button fixation of tibiofibular syndesmosis.

button fixation of tibiofibular syndesmosis (figure 2). He returned to work without complications 3 months after surgery.

\section{Learning points}

- Patient with ankle injuries should examine proximal fibula tenderness.

- Maisonneuve fracture is unstable injuries and require the patient to consult an orthopaedic surgeon.

Contributors $\mathrm{YJ}, \mathrm{KI}$ and MT contributed to patient management. RI drafted the initial manuscript. MT critically reviewed manuscript. All authors contributed to writing the manuscript and have provided written consent for publication.

Funding The authors have not declared a specific grant for this research from any funding agency in the public, commercial or not-for-profit sectors.

Competing interests None declared.

Figure 1 Left tibia-fibula anterior-posterior X-ray showed proximal fibula spiral fracture (arrow). 
Provenance and peer review Not commissioned; externally peer reviewed.

\section{REFERENCES}

1 Smeeing DPJ, Houwert RM, Kruyt MC, et al. The isolated posterior malleolar fracture and syndesmotic instability: a case report and review of the literature. Int I Surg Case Rep 2017;41:360-5.
2 Taweel NR, Raikin SM, Karanjia HN, et al. The proximal fibula should be examined in all patients with ankle injury: a case series of missed maisonneuve fractures. J Emerg Med 2013;44:e251-5.

3 Richmond RR, Henebry AD. A Maisonneuve fracture in an active duty sailor: a case report. Mil Med 2018;183:e278-80.

Copyright 2019 BMJ Publishing Group. All rights reserved. For permission to reuse any of this content visit https://www.bmj.com/company/products-services/rights-and-licensing/permissions/

BMJ Case Report Fellows may re-use this article for personal use and teaching without any further permission.

Become a Fellow of BMJ Case Reports today and you can:

- Submit as many cases as you like

- Enjoy fast sympathetic peer review and rapid publication of accepted articles

Access all the published articles

Re-use any of the published material for personal use and teaching without further permission

Customer Service

If you have any further queries about your subscription, please contact our customer services team on +44 (0) 2071111105 or via email at support@bmj.com.

Visit casereports.bmj.com for more articles like this and to become a Fellow 